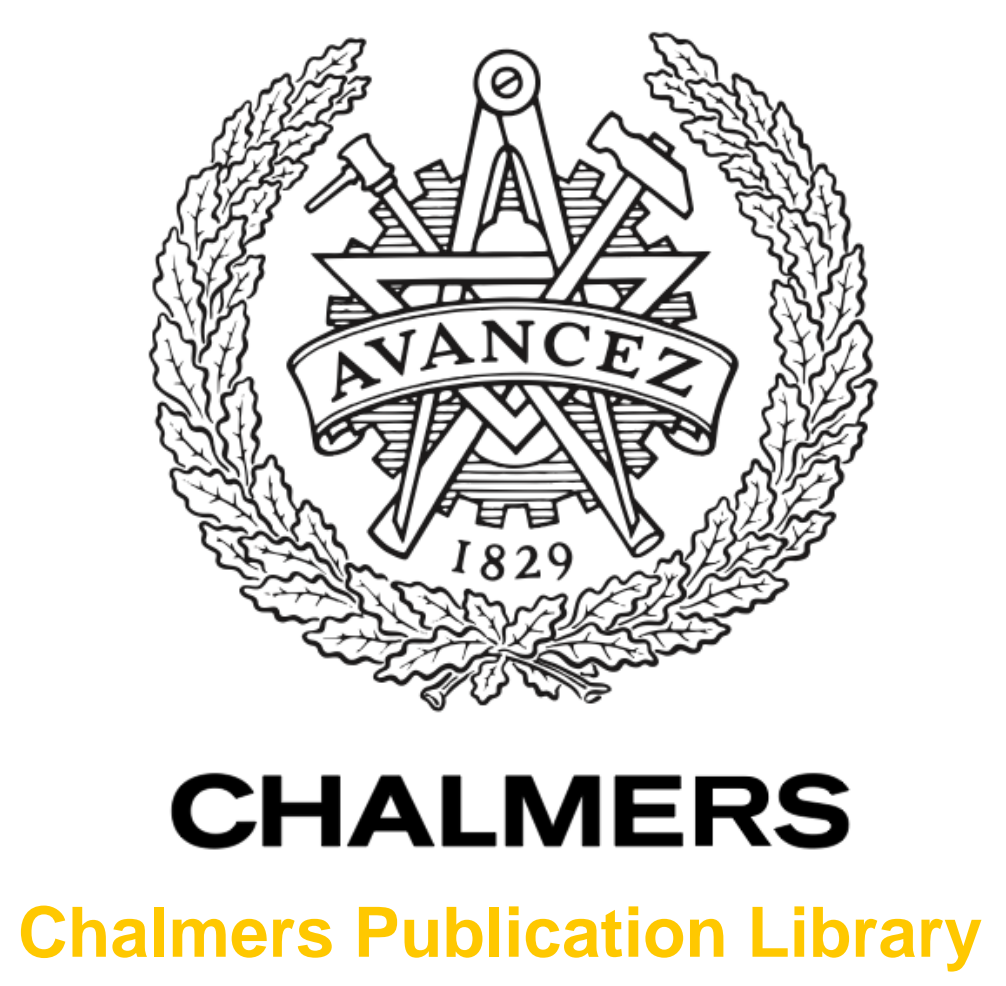

\title{
Leaching for recovery of copper from municipal solid waste incineration fly ash: Influence of ash properties and metal speciation.
}

This document has been downloaded from Chalmers Publication Library (CPL). It is the author's version of a work that was accepted for publication in:

Waste management \& research : the journal of the International Solid Wastes and Public Cleansing Association, ISWA (ISSN: 1399-3070)

Citation for the published paper:

Lassesson, H. ; Karlfeldt Fedje, K. ; Steenari, B. (2014) "Leaching for recovery of copper from municipal solid waste incineration fly ash: Influence of ash properties and metal speciation.". Waste management \& research : the journal of the International Solid Wastes and Public Cleansing Association, ISWA

http://dx.doi.org/10.1177/0734242X14542147

Downloaded from: http://publications.lib.chalmers.se/publication/201451

Notice: Changes introduced as a result of publishing processes such as copy-editing and formatting may not be reflected in this document. For a definitive version of this work, please refer to the published source. Please note that access to the published version might require a subscription. 
Leaching for recovery of $\mathrm{Cu}$ from MSWI fly ash - influence of ash properties and metal speciation

\author{
Lassesson, Henric ${ }^{1}$, Karlfeldt Fedje, Karin ${ }^{2,3}$ and Steenari, Britt-Marie ${ }^{1}$,
}

${ }^{1}$ Department of Chemical and Biological Engineering, Industrial Materials Recycling, Chalmers University of Technology, SE-412 96 Gothenburg, Sweden

${ }^{2}$ Recycling and Waste Management, Renova AB, Box 156, SE-401 22 Gothenburg, Sweden

${ }^{3}$ Water Energy Technology, Department of Civil and Environmental Engineering, Chalmers

University of Technology, SE-412 96 Gothenburg, Sweden 


\begin{abstract}
Recovery of metals occurring in significant amounts in MSWI fly ash, such as copper, could offer several advantages: a decreased amount of potentially mobile metal compounds going to landfill, saving of natural resources and a monetary value. A combination of leaching and solvent extraction may constitute a feasible recovery path for metals from MSWI fly ash. However, it has been shown that the initial dissolution and leaching is a limiting step in such a recovery process. The work described in this article was focused on elucidating physical and chemical differences between two ash samples with the aim of explaining the differences in copper release from these samples in two leaching methods.
\end{abstract}

The results showed that the chemical speciation is an important factor affecting the release of copper. The occurrence of copper as phosphate or silicate will hinder leaching, while sulphate and chloride will facilitate leaching.

Keywords: MSWI fly ash, copper speciation, X-ray absorption spectroscopy, ash properties, metal recovery, leaching 


\section{Introduction}

Development of methods to remove and recover metals from the fly ash from municipal solid waste incineration (MSWI) is presently being pursued (Schlumberger et al., 2007, Karlfeldt Fedje et al., 2010). Schlumberger and co-workers have described a process for the recovery of Zn from ash, including leaching with an acidic aqueous phase followed by a solvent extraction process and electrolysis for separation of Zn ions from the other metal ions present in the acid leachate. This process is presently being scaled up and implemented at combustion plants in Switzerland (Schlumberger and Bühler, 2012). Two processes for the recovery of copper from MSWI fly ashes using leaching and separation by solvent extraction were recently suggested by Karlfeldt Fedje and co-workers (Karlfeldt Fedje et al., 2012, Karlsson et al., 2010). The approaches tested were: 1) an acidic leaching, which gave a general release of many metals, and 2) leaching with an ammonium nitrate solution for the selective removal of copper. The leached fractions of the copper contents in fly ashes from different MSW combustors ranged from 40 to $100 \%$ of the total copper content. These differences could not be explained by differences in combustion methods or other obvious factors, such as the fuel composition or flue gas cleaning system. Therefore the investigation presented in this paper was carried out with the aim of clarifying possible reasons for the observed differences between two fly ashes releasing $60 \%$ and $100 \%$ of their copper contents.

The low concentration of minor and trace metals in fly ash, in addition to the complex nature of the ash matrix, makes direct analytical speciation of these metals, for example by XRD, difficult. One approach has been to use sequential extraction methods (Tessier et al., 1979, Kirby and Rimstidt, 1993, Chou et al., 2009). Previous results from sequential extraction investigations of Ash A (which is described in the Materials and Methods section) has indicated that copper would 
be mainly (>80\%) bound to carbonates and to iron oxides and/or manganese oxides, and the amount of water soluble compounds would be less than 1\% (Karlfeldt, 2006). However, sequential extraction leads to chemical and physical alterations in the major matrix compounds and consequently also results in chemical transformation of the trace metal compounds. These processes have a significant influence on the experimental results, which has also been extensively discussed in the literature (Usero et al., 1998, Gómez Ariza et al., 2000, Sutherland and Tack, 2003).

In recent years synchrotron based X-ray absorption spectroscopy (XAS) has become an alternative for direct investigation of oxidation states and the speciation of metals in various materials, such as ash (Huggins et al., 2000, Yu et al., 2009, Camerani et al., 2007, Funatsuki et al., 2012). Recent investigations of copper speciation in MSWI fly ash (Tuan et al., 2010, Tian et al., 2009, Hsiao et al., 2006, Takaoka et al., 2005, Takaoka et al., 2008) have reported quite varying results. Copper is primarily reported to be in oxidation state +II in fly ashes, with oxides, hydroxides, chlorides and sulphates as the most common compounds, in varying concentrations.

An investigation of the copper speciation in the different ash flows from a bubbling fluidized bed boiler fired with MSW using XAS methods has recently been carried out by Lassesson and coworkers (Lassesson and Steenari, 2013). The results showed that copper occurred mainly as copper metal, copper oxides $\left(\mathrm{CuO}\right.$ and $\left.\mathrm{Cu}_{2} \mathrm{O}\right)$ and mixed oxides (e.g. $\left.\mathrm{CuCr}_{2} \mathrm{O}_{4}\right)$ in the ashes from, and close to, the combustion bed. The results also showed that the concentration of copper chlorides, hydroxides and sulphate increased further down the BFB flue gas system. Ash A in the work described here was taken from the same BFB boiler during the same time period. 
The aim of the work presented here was to find explanations to the different behaviour shown by two MSWI fly ashes in leaching processes designed for recovery of metals from ash.

\section{Materials and Methods}

Two MSWI fly ash samples from those presented by Karlfeldt Fedje and co-workers (Karlfeldt Fedje et al., 2012) were chosen to be included in this investigation. Ash sample A was a bag house filter ash from a bubbling fluidized bed boiler (BFB) and Ash B came from a mass burn combustor and was collected in an electric precipitator. In both cases sorted household waste was the main fuel, with minor additions of industry waste, such as plastics, wood and paper. At the BFB combustor slaked lime $\left(\mathrm{Ca}(\mathrm{OH})_{2}\right)$ was added before the filter to absorb acidic gases. The concentrations of main elements and copper in the ashes are shown in Table 1. Ash samples were taken with regular intervals during several weeks and mixed to a bulk sample. The analyses were done by an accredited laboratory according to standard methods after homogenising the samples and dividing them according to the standardized procedure for granular wastes. Element concentrations in ash samples were determined, after total dissolution, by inductively coupled plasma atomic emission spectrometry (ICP-AES) for main elements and inductively coupled plasma mass spectrometry (ICP-MS) for trace elements. The concentrations in Table 1 are given with a reduced number of digits not to indicate a higher precision than possible due to the small amount of ash taken for dissolution.

The ash samples were leached for $24 \mathrm{~h}$ with $3 \mathrm{M} \mathrm{NH}_{4} \mathrm{NO}_{3}$ at $\mathrm{pH} 9$ and with $3 \mathrm{M} \mathrm{HNO}_{3}$ at $\mathrm{pH} 2$. More detailed information about the leaching experiments and the subsequent copper separation can be found in (Karlfeldt Fedje et al., 2012). Ash A corresponds to Ash 3 and Ash B to Ash 5 in the paper by Karlfeldt Fedje and co-workers. 
Table 1. Total concentrations of major elements and $\mathrm{Cu}$ in the fly ash samples. Data from (Karlfeldt Fedje et al., 2012)

\begin{tabular}{|l|r|r|}
\hline Major elements & \multicolumn{1}{l|}{ Ash A } & \multicolumn{1}{l|}{ Ash B } \\
\hline$\left(\mathrm{mg} \mathrm{kg}^{-1}\right.$ dry ash $)$ & & \\
\hline $\mathrm{Al}$ & 20000 & 30000 \\
\hline $\mathrm{Ca}$ & 360000 & 120000 \\
\hline $\mathrm{Fe}$ & 5600 & 24000 \\
\hline $\mathrm{K}$ & 25000 & 70000 \\
\hline $\mathrm{Mg}$ & 10000 & 12000 \\
\hline $\mathrm{Na}$ & 30000 & 80000 \\
\hline $\mathrm{P}$ & 4000 & 6000 \\
\hline $\mathrm{S}$ & 35000 & 75000 \\
\hline $\mathrm{Si}$ & 200000 & 70000 \\
\hline $\mathrm{Cl}$ & 5400 & 2500 \\
\hline $\mathrm{Cu}$ & &
\end{tabular}

The main crystalline compounds in the original and leached ash samples were identified by qualitative X-ray powder diffractometry (XRD) using a Siemens D5000 X-ray powder diffractometer with characteristic $\mathrm{Cu}$ radiation and a scintillation detector. Identification of compounds was carried out using the Joint Committee of Powder Diffraction Standards database (JCPDS, 2013). The detection limit of this method is about $1 \%$ by weight.

Scanning electron microscopy coupled with energy dispersive X-ray fluorescence element analysis (SEM-EDX) was used to examine the morphology of ash particles, both before and after leaching experiments. The microscope used was a FEI Quanta 200 FEG ESEM, operated at 2-12 $\mathrm{kV}$ for secondary electron imaging, coupled with an Oxford Inca 300 energy dispersive X-ray (EDX) system. 
The speciation of copper in solid ash samples was investigated using X-ray absorption fine structure (XAS) spectroscopy measurements at the MAX-lab synchrotron (managed by Lund University, Sweden). XAS data was also collected for a number of pure compounds that were used for comparison. The following 23 standard compounds were used: $\mathrm{Cu}$, brass $(\mathrm{Cu} / \mathrm{Zn}$ alloy), $\mathrm{Cu}_{2} \mathrm{O}, \mathrm{CuO}, \mathrm{CuCrO}_{2}, \mathrm{CuCr}_{2} \mathrm{O}_{4}, \mathrm{CuFe}_{2} \mathrm{O}_{4}, \mathrm{Cu}_{3}\left(\mathrm{PO}_{4}\right)_{2}, \mathrm{CuCl}, \mathrm{CuCl}_{2} \cdot 2 \mathrm{H}_{2} \mathrm{O}, \mathrm{CuClOH} / \mathrm{CuCl}$, $\mathrm{Cu}_{2} \mathrm{Cl}(\mathrm{OH})_{3}, \mathrm{Cu}(\mathrm{OH})_{2} \mathrm{CuCO}_{3} / \mathrm{CuCO}_{3}, \mathrm{Cu}(\mathrm{OH})_{2}, \mathrm{CuSO}_{4} \cdot 5 \mathrm{H}_{2} \mathrm{O}, \mathrm{CuSiO}_{3} \cdot \mathrm{H}_{2} \mathrm{O}, \mathrm{CuBr}_{2}, \mathrm{CuS}, \mathrm{Cu}_{2} \mathrm{~S}$, $\mathrm{Cu}_{5} \mathrm{FeS}_{4} / \mathrm{Cu}_{2} \mathrm{~S}$, CuCaOxide, $\mathrm{CuCaPhosphate} \mathrm{and} \mathrm{Chrysocolla.} \mathrm{Consequently,} \mathrm{this} \mathrm{investigation}$ has included more reference compounds than any of the other published studies on copper speciation in ashes. It is only possible to identify a specific compound through linear combination fitting of XAS data if it is available as a reference.

All standard compounds were analyzed with XRD and identified as pure, i.e. $<2 \%$ impurities, with the exception of $\mathrm{CuClOH} / \mathrm{CuCl}, \mathrm{Cu}(\mathrm{OH})_{2} \mathrm{CuCO}_{3} / \mathrm{CuCO}_{3}, \mathrm{Cu}_{5} \mathrm{FeS}_{4} / \mathrm{Cu}_{2} \mathrm{~S}, \mathrm{CuCaOxide}$, CuCaPhosphate and Chrysocolla. The $\mathrm{CuClOH} / \mathrm{CuCl}$ was identified by $\mathrm{XRD}$ and $\mathrm{XAS}$ as $\mathrm{CuClOH}$ with a small fraction $(\leq 7 \%)$ of $\mathrm{CuCl}$. The $\mathrm{Cu}(\mathrm{OH})_{2} \mathrm{CuCO}_{3} / \mathrm{CuCO}_{3}$ was identified by $\mathrm{XRD}$ and TGA as $\mathrm{Cu}(\mathrm{OH})_{2} \mathrm{CuCO}_{3}$ with a small fraction ( 12\%) of $\mathrm{CuCO}_{3}$. The $\mathrm{Cu}_{5} \mathrm{FeS}_{4} / \mathrm{Cu}_{2} \mathrm{~S}$ was identified by $\mathrm{XRD}$ as $\mathrm{Cu}_{5} \mathrm{FeS}_{4}$ with a small fraction (not quantified) of $\mathrm{Cu}_{2} \mathrm{~S}$. The CuCaOxide was identified by XRD as several mixed oxides of copper and calcium, one example being $\mathrm{Cu}_{2} \mathrm{CaO}_{3}$. The $\mathrm{CuCaPhosphate} \mathrm{was} \mathrm{identified} \mathrm{by} \mathrm{XRD} \mathrm{as} \mathrm{being} \mathrm{mainly} \mathrm{Ca}_{21-\mathrm{X}} \mathrm{Cu}_{\mathrm{X}}\left(\mathrm{PO}_{4}\right)_{14}$, with $x=1,2$ or 3 . The natural copper silicate mineral Chrysocolla, with formula $(\mathrm{Cu}, \mathrm{Al})_{2} \mathrm{H}_{2} \mathrm{Si}_{2} \mathrm{O}_{5}(\mathrm{OH})_{4} \cdot \mathrm{nH}_{2} \mathrm{O}$, was identified by XRD as a chrysocolla mineral free from crystalline impurities, i.e. other copper compounds. However, this mineral contains an amorphous part in which it was not possible to determine the exact chemical environment of the copper atoms. The EXAFS pattern corresponds well with what is previously reported in 
literature, e.g. (Farges et al., 2007). However, as Farges et al. points out, the EXAFS pattern is also quite similar to that of $\mathrm{Cu}(\mathrm{OH})_{2}$.

The mixed oxides $\mathrm{CuCrO}_{2}, \mathrm{CuCr}_{2} \mathrm{O}_{4}, \mathrm{CuFe}_{2} \mathrm{O}_{4}$ and $\mathrm{CuCaOxide}$ were synthesized in laboratory scale heating experiments. These experiments were conducted in a separate project, reported in (Lassesson, 2013), where the reactivity of copper compounds with common ash components at relevant temperatures was investigated. The result did however also include compounds which could be used as materials for comparison in XAS investigations since their formation in combustion is possible. Powder form copper oxide $\left(\mathrm{Cu}_{2} \mathrm{O}\right.$ or $\left.\mathrm{CuO}\right)$ was mixed with powdered $\mathrm{Cr}_{2} \mathrm{O}_{3}, \mathrm{Fe}_{2} \mathrm{O}_{3}$ or $\mathrm{CaO}$ in a mortar, and then put into a pre-heated oven at $700^{\circ} \mathrm{C}\left(\mathrm{CuCr}_{2} \mathrm{O}_{4}\right)$, $950^{\circ} \mathrm{C}\left(\mathrm{CuFe}_{2} \mathrm{O}_{4}\right)$ or $1050^{\circ} \mathrm{C}\left(\mathrm{CuCrO}_{2}, \mathrm{CuCaOxide}\right)$ for $24 \mathrm{~h}$ or more. All samples were in contact with air during the heating experiments, which means that $\mathrm{Cu}_{2} \mathrm{O}$ and $\mathrm{CuO}$ were interchangeable. The CuCaPhosphate was also synthesized in a similar experiment, where copper chloride $\left(\mathrm{CuCl}\right.$ or $\left.\mathrm{CuCl}_{2}\right)$ was mixed with $\mathrm{Ca}_{3}\left(\mathrm{PO}_{4}\right)_{2}$ and left to react at $1050^{\circ} \mathrm{C}$. The same results were achieved with both chlorides. Most of the copper chloride evaporated almost immediately, but some of it reacted with the calcium phosphate and resulted in mixed copper calcium phosphate. The results from these experiments agree well with results found in the literature (Neumann et al., 1984, Stroupe, 1949, Mathews et al., 1993, Jacob et al., 1977, Sułowska et al., 2012). More detailed information about the heating experiments can be found in (Lassesson, 2013).

Copper K-edges spectra were collected at room temperature and at ambient atmospheric pressure at beamline I811 using a $\mathrm{Si}(111)$ double crystal monochromator. The monochromator was detuned to $30 \%$ below maximum intensity to remove higher order harmonics. All spectra were 
calibrated by assigning the first inflection point of the $\mathrm{Cu}$ metal K-edge to $8979 \mathrm{eV}$. The sample spectra were collected in fluorescence mode by either a Lytle detector or a solid state PIPS detector and the metal foil data for energy calibration was simultaneously collected in transmission mode by ionization chambers. Each XAS spectrum represents the average of two or more scans. Linear combinations of XANES data for pure compounds were used to model the semi-quantitative speciation of copper in the ash samples. Similar linear combination fitting (LCF) of the EXAFS region of the data was also made using Athena software (Ravel and Newville, 2005). Spectra have been collected on more than one occasion for three of the ash samples included in this study and several other ash samples as well. Only minor differences could be found between two spectra of the same sample, although the measurements where collected on different parts of the same sample and some time had passed between XAS measurements. This indicates that the homogeneity of ashes is adequate for this type of analysis.

\section{Results and discussion}

The copper contents of the fly ashes studied in this work were $5400 \mathrm{mg} \mathrm{kg}^{-1}$ in Ash A and 2500 $\mathrm{mg} \mathrm{kg}^{-1}$ in Ash B, which are quite typical copper contents in fly ashes from MSWI in Sweden. Literature data on MSWI fly ash indicates that different combustor designs, such as fluidized bed combustors and mass burn combustors, may give fly ashes with different amounts of minor metals such as copper (ALLASKA, 2011). Data on copper contents in fly ash from Swedish solid waste units shows that fly ash from bubbling fluidized bed (BFB) boilers contains on average $5500 \mathrm{mg}$ Cu per kg dry ash (700 - $16400 \mathrm{mg} \mathrm{kg}^{-1}$, from 23 data points) in comparison to fly ash from grate-fired boilers, which has an average content of $2300 \mathrm{mg}$ Cu per kg ash (100 $8200 \mathrm{mg} \mathrm{kg}^{-1}$, from 22 data points). This data indicates that copper generally has a similar abundance in both types of ash, however it is somewhat higher in BFBs. In a fluidized bed 
combustor the bed temperature is nominally $850^{\circ} \mathrm{C}$, whereas the temperature in the fuel bed on a grate can reach well over $1000^{\circ} \mathrm{C}$. A higher temperature in the combustion zone will promote vaporization of metal compounds with low boiling points, such as chlorides. To some extent the lime injected before the filter in the FBC unit leads to a dilution of the trace metals in the ash collected in the filter. Some dilution due to entrainment of quartz $\left(\mathrm{SiO}_{2}\right)$ from the bed sand in the FBC is possible, but in general this is negligible for the fine grained filter ash since most of the entrained sand is separated in the cyclone. The data obtained from X-ray powder diffraction (Table 2) confirmed that quartz from the bed material is not a major mineral component in any of the ash samples. Calcium compounds dominated the mineralogy of Ash A, as expected from the lime addition, but Ash B also contained significant amounts of calcium compounds, such as carbonate and sulphate formed from the fuel.

Table 2. Crystalline compounds identified in ash samples A and B. The analyses are semi quantitative estimates, where the amounts are related to the area under the peaks of the diffraction diagram.

\begin{tabular}{|l|l|l|l|l|l|l|}
\hline Compound & \multicolumn{3}{|c|}{ Ash A } & \multicolumn{3}{c|}{ Ash B } \\
\hline & Untreated & $\begin{array}{l}\text { After } \mathrm{NH}_{4} \mathrm{NO}_{3} \\
\text { leaching }\end{array}$ & $\begin{array}{l}\text { After } \mathrm{HNO}_{3} \\
\text { leaching }\end{array}$ & Untreated & $\begin{array}{l}\text { After } \mathrm{NH}_{4} \mathrm{NO}_{3} \\
\text { leaching }\end{array}$ & $\begin{array}{l}\text { After } \mathrm{HNO}_{3} \\
\text { leaching }\end{array}$ \\
\hline $\mathrm{NaCl}$ & Dominant & & & Dominant & & \\
\hline $\mathrm{KCl}$ & Dominant & & & Sub-dominant & & \\
\hline $\mathrm{KCaCl}$ & Minor & & & & & \\
\hline $\mathrm{Ca}(\mathrm{OH})_{2}$ & Dominant & & & Minor & & \\
\hline $\mathrm{CaClOH}$ & Dominant & & & & & \\
\hline $\mathrm{CaCO}_{3}$ & Dominant & Dominant & Sub-dominant & Sub-dominant & Sub-dominant & Sub-dominant \\
\hline $\mathrm{CaSO}_{4}$ & Minor & & & Sub-dominant & Sub-dominant & \\
\hline $\mathrm{CaSO}_{4} \cdot 2 \mathrm{H}_{2} \mathrm{O}$ & & Sub-dominant & Dominant & & & Dominant \\
\hline $\mathrm{Ca}_{3} \mathrm{Al}_{2} \mathrm{O}_{6}$ & Minor & Sub-dominant & Sub-dominant & Minor & Minor & Sub-dominant \\
\hline $\mathrm{SiO}_{2}$ & Minor & Minor & Minor & Minor & Minor & Sub-dominant \\
\hline
\end{tabular}


After leaching the mineralogy of both ashes is dominated by calcium carbonate and gypsum, formed as secondary compounds. SEM-EDX also showed the presence of gypsum crystals in the leached samples, especially for acid leached Ash B.

Both leaching methods resulted in significant release of copper. However, the ashes behaved differently. For Ash A the copper leaching amounted to approximately 100\% in both leaching liquids, whereas leaching from Ash B amounted to 60\%. The alkaline ammonium nitrate leaching, applied to five ashes (including ashes $\mathrm{A}$ and $\mathrm{B}$ ), also removed most of the $\mathrm{K}$ and $\mathrm{Na}$, as well as $10 \%-65 \%$ of the Ca and $25 \%-80 \%$ of the $\mathrm{Zn}$. The acid leaching removed a major portion of the Ca, K, Mg, Mn, Na, Pb and Zn from the ash content (Karlfeldt Fedje et al., 2010). The total reduction in ash mass was 50\% for Ash A and 40\% for Ash B during the ammonium nitrate leaching and 70\% for Ash A and 40\% for Ash B during the acid leaching.

The specific surface area data shows that both leaching methods gave significantly increased surface areas for both ashes (Table 3). However, the largest increase was observed for acid leached Ash A, giving a surface area more than four times larger than that of acid leached Ash B.

Table 3. Specific surface areas $\left(\mathrm{m}^{2} \mathrm{~g}^{-1}\right)$ of original and leached filter ashes A and B.

\begin{tabular}{|l|l|l|l|}
\hline Ash & \multicolumn{3}{|c|}{ Specific surface area $\left(\mathbf{m}^{2} \mathbf{g}^{-1}\right)$} \\
\hline & Untreated ash & Ash leached with $\mathrm{NH}_{4} \mathrm{NO}_{3}$ & Ash leached with $\mathrm{HNO}_{3}$ \\
\hline A & 5.1 & 21.7 & 110 \\
\hline B & 3.1 & 14.2 & 26.2 \\
\hline
\end{tabular}

From electron microscopy (Figure 1a) it was clear that most of the ash particles in both samples were in fact aggregates of smaller particles. 

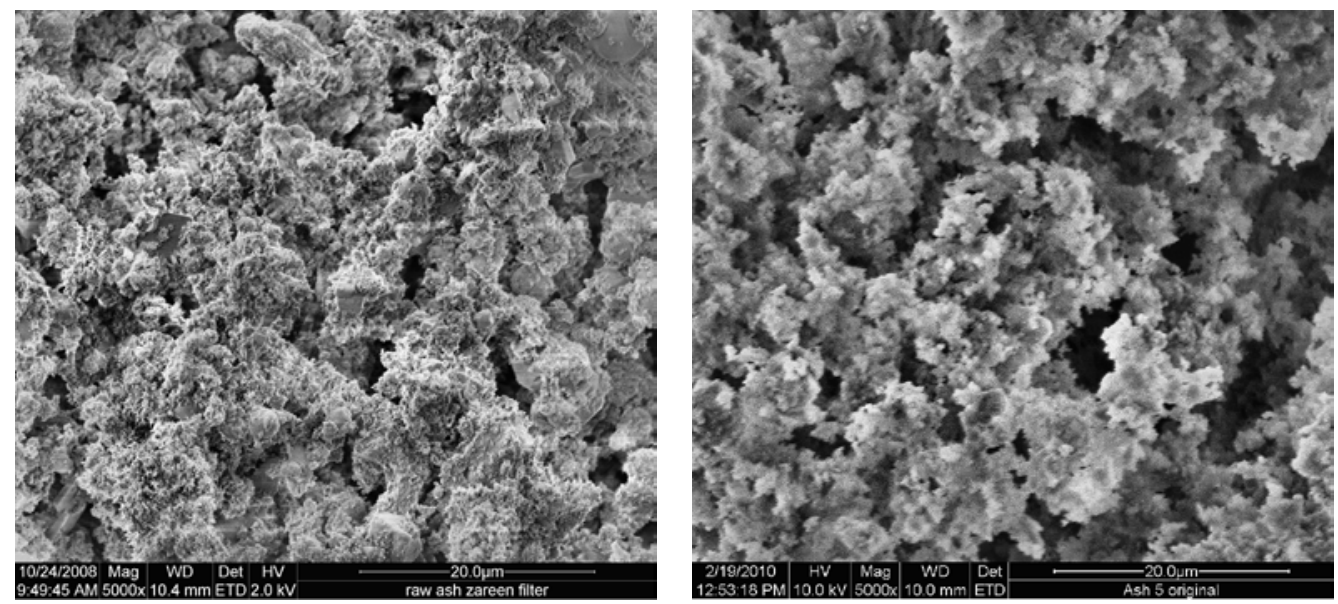

Figure 1a. SEM photos of untreated Ash A (left) and Ash B (right).
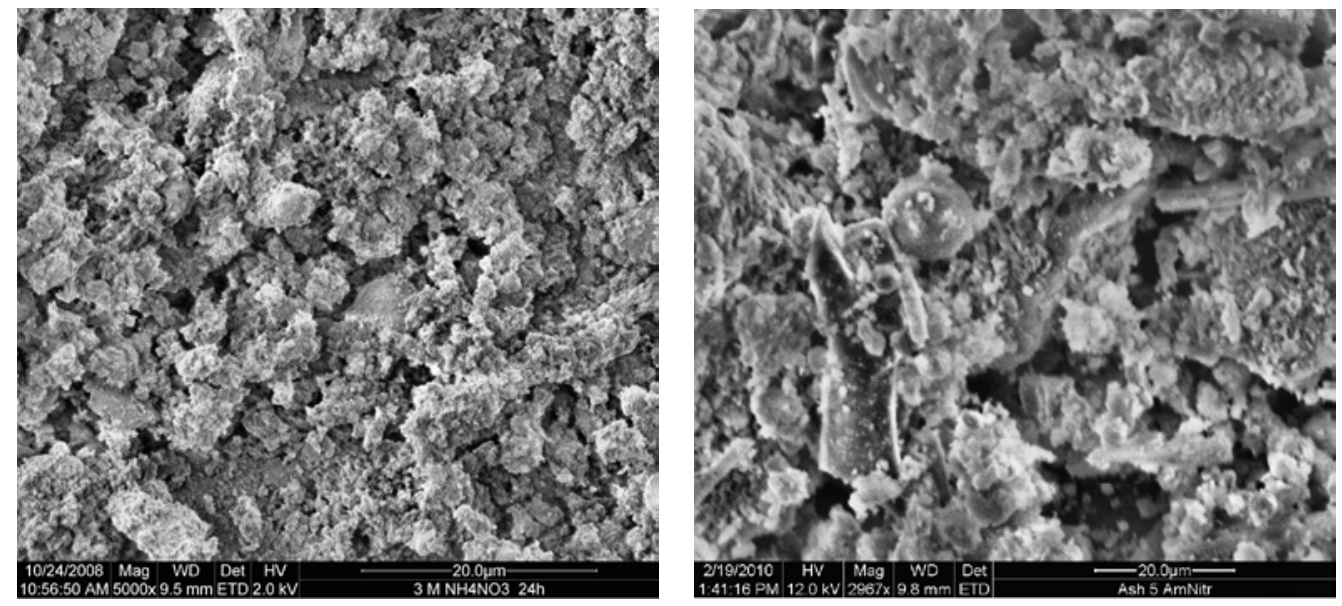

Figure 1 b. Ash A (left) and Ash B (right) leached in $\mathrm{NH}_{4} \mathrm{NO}_{3}$
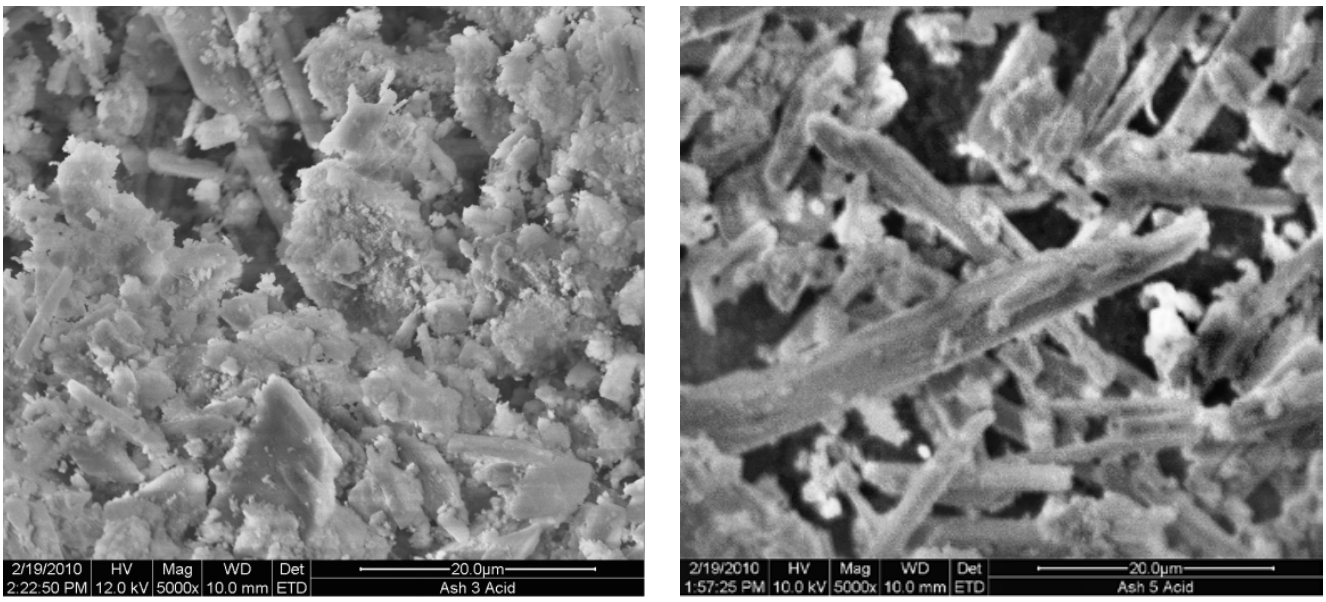

Figure 1 c. Ash A (left) and Ash B (right) leached in $\mathrm{HNO}_{3}$ 
The SEM images show that the particle size of both ashes was only slightly affected by the ammonium nitrate leaching. However, the residues from acid leaching showed an increase in particle size, mainly due to precipitation of needle-like gypsum crystals (Figure 1c), which also affected the specific surface area. The crystals were on average $20-40 \mu \mathrm{m}$ long and had a cross section of a few $\mu$ m. EDX showed that these crystals actually were crystals of gypsum, which fits well with the XRD results (Table 2). Formation of gypsum occurred also during leaching of Ash A, but the crystallization conditions seemed to favour smaller size crystals in comparison to those formed during the leaching of Ash B (Figure 1c). Due to the small size of the ash particles and their tendency to agglomerate into clusters it was not possible to study the distribution of elements in the particles in detail by EDX. The resolution of the EDX results is considerably lower than the resolution of the SEM micrograph. The increase in specific surface area for both samples was larger when leaching with acid was applied than during leaching with ammonium nitrate. The increase was also significantly larger for Ash A than for Ash B. The large specific surface area could be due to increased porosity, but the data available cannot verify that.

Application of linear combination fitting (LCF) analysis to Cu K-edge XANES and EXAFS data gave probable speciation of copper in untreated samples of Ash A and Ash B, as well as after leaching with $\mathrm{HNO}_{3}$ or $\mathrm{NH}_{4} \mathrm{NO}_{3}$. All percentages shown in these results are atomic-percent, i.e. the number of copper atoms in a specific compound compared to the total number of copper atoms. It should be noted that the linear combination fitting method gives only semi-quantitative concentrations of compounds. The XAS Cu K-edge spectra for ash samples, leaching residues and relevant standard compounds are shown in Figure 2, along with the LCF modelling results. The LCF modelling results are compiled in Table 4. It is seldom that the LCF modelling will result in the exact same best fit in both the XANES and EXAFS regions. Illustrated in Figure 2 
and Table 4 are instead approximations based on results from both regions, i.e. these are chosen to fit as well as possible in both regions. The approximations, with one exception, are multiples of $5 \%$ in order not to indicate a higher precision than possible, due to the small amount of ash and similarities between the reference compounds. The only exception is the metallic copper which has a strong EXAFS signal, not similar to any other reference compound (except brass), which makes it easier to detect with higher certainty.

The results indicate that copper in Ash A predominantly exists in oxidized form as copper(II) species, such as sulphate, hydroxides and chlorides. This is illustrated in Figure 2 with $70 \%$ $\mathrm{CuSO}_{4} \cdot 5 \mathrm{H}_{2} \mathrm{O}$ and $30 \% \mathrm{CuClOH} / \mathrm{CuCl}$. Ash B showed a more varied speciation, with oxidation states 0, I and II. A combination of $15 \%$ metallic $\mathrm{Cu}, 15 \% \mathrm{Cu}_{2} \mathrm{~S}, 15 \% \mathrm{CuO}$ and $55 \% \mathrm{Cu}_{3}\left(\mathrm{PO}_{4}\right)_{2}$ explains the XANES spectrum and the EXAFS features quite well. Unfortunately, the copper sulphides $\left(\mathrm{Cu}_{2} \mathrm{~S}, \mathrm{Cu}_{5} \mathrm{FeS}_{4}\right.$ and $\left.\mathrm{CuS}\right)$, as well as $\mathrm{CuCl}$, have quite similar $\mathrm{XAS}$ spectra. This means that these are hard to differentiate in the LCF, especially in lower amounts. The same goes for $\mathrm{Cu}_{3}\left(\mathrm{PO}_{4}\right)_{2}$ and $\mathrm{CuSiO}_{3} \cdot \mathrm{H}_{2} \mathrm{O}$. The other copper silicate (Chrysocolla) showed some similarities with the phosphate/silicate as well, but was easier to distinguish. Similarities in XAS spectra from two samples occur when the copper has the same oxidation state and approximately the same amount of neighbouring atoms with similar atomic number at similar distances, which is the case here. It might seem counterintuitive, but as it turns out, all three copper sulphides have the same oxidation state, i.e. Cu(I) (van der Laan et al., 1992, Pearce et al., 2006, Goh et al., 2006). In this study it was seen that the XAS spectra of the phosphate $\left(\mathrm{Cu}_{3}\left(\mathrm{PO}_{4}\right)_{2}\right)$ seemed to fit slightly better than the silicates and the sulphide $\left(\mathrm{Cu}_{2} \mathrm{~S}\right)$ seemed to fit slightly better than the $\mathrm{CuCl}$ and $\mathrm{CuS}$, with almost no difference to $\mathrm{Cu}_{5} \mathrm{FeS}_{4}$, which is why these two were chosen in the LCF illustrated in Figure 2 and Table 4. 
The main difference between Ash A and Ash B is that Ash B does not contain any observable amounts of $\mathrm{CuSO}_{4} \cdot 5 \mathrm{H}_{2} \mathrm{O}$ or $\mathrm{Cu}(\mathrm{II})$ chloride, but contains predominately $\mathrm{Cu}_{3}\left(\mathrm{PO}_{4}\right)_{2}$ (or $\mathrm{CuSiO}_{3} \cdot \mathrm{H}_{2} \mathrm{O}$ ) combined with $\mathrm{Cu}_{2} \mathrm{~S}$ (or $\mathrm{CuCl}$ or any other $\mathrm{Cu}$-sulphide) and $\mathrm{CuO}$ and $\mathrm{Cu}$ metal, i.e. compounds with low solubility. The low amounts of copper in low oxidation states in Ash A shows that oxidizing conditions have dominated during the combustion in the BFB. The grate fired MB boiler from which Ash B originated seems to have reducing zones, since the ash contains copper species with low oxidation states. Reducing zones can also contribute to the formation of copper sulphides. Another possibility is that copper is present in finely dispersed particles that travel rapidly through the combustion zone and the flue gas channel and do not have time to become fully oxidized.

The XAS spectra for the Ash B sample after leaching with ammonium nitrate (Res. B am.nitr.) showed that metallic copper was preferably released from ash during this leaching process. Metallic copper was completely removed from the Ash B sample and the fraction of $\mathrm{CuO}$ of the remaining copper content in the ash was $30 \%$, while the fraction of the less soluble $\mathrm{Cu}_{3}\left(\mathrm{PO}_{4}\right)_{2}$ / $\mathrm{CuSiO}_{3} \cdot \mathrm{H}_{2} \mathrm{O}$ was $55 \%$. In total about $40 \%$ of the initial copper content remained in the solid phase after leaching. As can be seen in Figure 2 and Table 4 the XAS data obtained for the residue of Ash A after leaching with ammonium nitrate (Res. A am.nitr.) displays clear similarities to those of Res. B am.nitr., with some additional metallic copper and $\mathrm{CuCr}_{2} \mathrm{O}_{4}$. None of the identified compounds in the residue of Ash A were identified in the untreated ash. This could be a result of the almost complete dissolution of copper in the sample. Since almost $100 \%$ of copper was dissolved, it is most likely that small amounts of less soluble (or encapsulated) compounds became more concentrated, compared to the total number of copper atoms in the sample. The $\mathrm{CuCr}_{2} \mathrm{O}_{4}$ as well as $\mathrm{CuO}$ and metallic $\mathrm{Cu}$ have all been identified in other ash 
fractions (e.g. bottom bed ash) from the same boiler and on the same occasion (Lassesson et.al. 2013). Metallic copper pieces may have been covered by glass melt in the combustion bed. This has been observed in other (unpublished) work.

XAS spectra for both residues of acid-leached ashes (Res. A acid and Res. B acid) look quite similar to those obtained for the ammonium nitrate-leached ashes. The best fits for XAS results were obtained when CuCaPhosphate was included in the LCF. It seems as if some sort of precipitation has occurred, since the CuCaPhosphate was not present in either the original ashes or in the ammonium nitrate residues. 

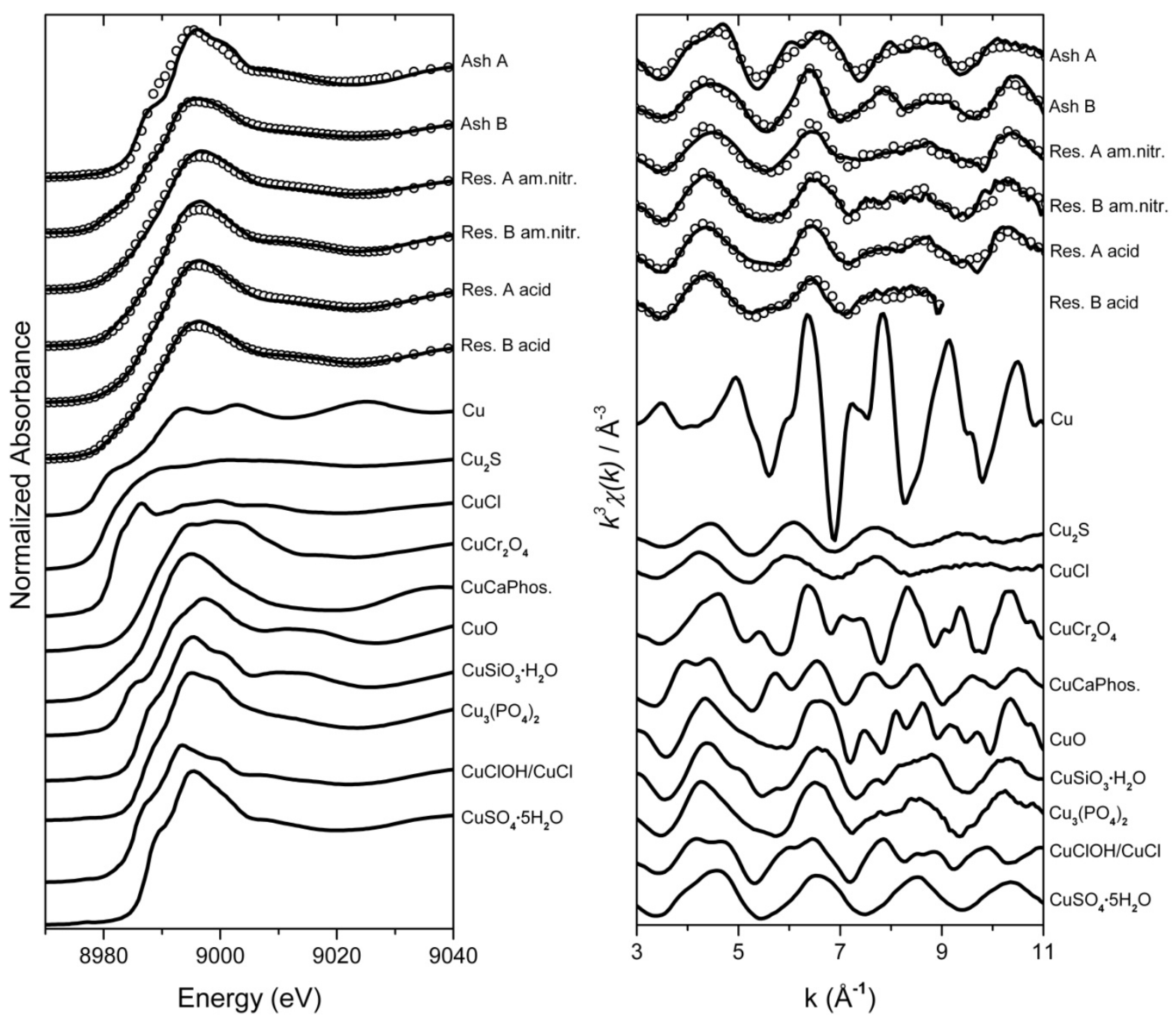

Figure 2. Cu K-edge XANES data (left) and $k^{3}$-amplified EXAFS data (right) for standards and ash samples (solid lines) with estimates from LCF (circles). The LCF estimates are presented in Table 4. 
Table 4. Estimates from linear combination fitting (LCF) of ashes and solid residues from leaching in $\mathrm{HNO}_{3}$ or $\mathrm{NH}_{4} \mathrm{NO}_{3}$. The estimates are chosen to fit as well as possible in both the XANES and the EXAFS regions.

\begin{tabular}{|l|l|l|l|l|l|l|l|l|}
\hline Sample & $\mathbf{C u}$ & $\mathbf{C u} \mathbf{S}$ & $\mathbf{C u C a P h o s}$ & $\mathbf{C u O}$ & $\mathbf{C u}_{3}\left(\mathbf{P O}_{4}\right)_{2}$ & $\mathbf{C u C r}_{2} \mathbf{O}_{4}$ & $\mathbf{C u S O}_{4} \cdot 5 \mathbf{H}_{2} \mathbf{O}$ & $\mathbf{C u C l O H}$ \\
\hline Ash A & & & & & & & $70 \%$ & $30 \%$ \\
\hline Ash B & $15 \%$ & $15 \%$ & & $15 \%$ & $55 \%$ & & & \\
\hline Res. A am.nitr. & $5 \%$ & $15 \%$ & & $25 \%$ & $45 \%$ & $10 \%$ & & \\
\hline Res. B am.nitr. & & $15 \%$ & & $30 \%$ & $55 \%$ & & & \\
\hline Res. A acid & $3 \%$ & $12 \%$ & $10 \%$ & $15 \%$ & $55 \%$ & $5 \%$ & & \\
\hline Res. B acid & & $30 \%$ & $20 \%$ & $10 \%$ & $40 \%$ & & & \\
\hline
\end{tabular}

\section{Summary and conclusions}

In this work it was observed that, during the leaching processes, the particle size and the specific surface area of Ash A was more affected than that of Ash B. The acid leaching of Ash A resulted in gypsum precipitation and a specific surface area four times larger than that of the residue from the ammonium nitrate leaching. However, no difference in copper release (almost 100\%) was observed between the leaching methods. Both leaching methods resulted in a $60 \%$ release of copper from Ash B. The specific surface area of this ash increased during leaching as well, however not as much as for Ash A, although gypsum formation was observed for this ash as well during the acid leaching.

To summarize, the observed physical changes induced by the leaching processes did not explain the differences in copper release for the two ashes studied.

The XAS results indicate copper compounds with higher solubility in Ash A (sulphate, hydroxides and chlorides) than in Ash B, which explains the differences in copper yield during 
leaching. The less soluble compounds of Ash B (Cu(II)phosphate/-silicate along with $\mathrm{Cu}(\mathrm{II})$ oxide and $\mathrm{Cu}(\mathrm{I})$ sulphide/-chloride) remained in the residues. The residues of both ashes showed remarkable similarities in copper speciation, from both acid leaching and ammonium nitrate leaching. The residues also showed large similarities, in copper speciation, with the untreated Ash B, which helps to explain the lower solubility of copper in that sample.

The conclusion of the present work is that the speciation of copper in MSWI fly ash is important for the yield of copper from a leaching process.

\section{Acknowledgements}

This work has been funded by Formas (The Swedish Research Council for Environment, Agricultural Sciences and Spatial Planning), the Swedish Energy Agency and Chalmers Area of Advance Energy, which is gratefully acknowledged. The work has been carried out within the graduate school Polytechnic Waste Research in Sweden-POWRES, also funded by FORMAS.

The authors also want to express their gratitude to Lena Fogelqvist, Stellan Holgersson, Kristian Larsson and Brita Ohlsson (all at Chalmers), for their assistance with laboratory work and to Stefan Carlson, Katarina Norén and the staff at the MAX IV Laboratory for making the XAS measurements possible. 


\section{References}

ALLASKA (2011) Database within the programme on ashes at Värmeforsk. Environmentally correct utilisation of ashes. Updated 2011-07-14 ed., Värmeforsk (Swedish Thermal Engineering Research Institute).

CAMERANI, M. C., SOMOGYI, A., VEKEMANS, B., ANSELL, S., SIMIONOVICI, A. S., STEENARI, B.-M. \& PANAS, I. (2007) Determination of the Cd-Bearing Phases in Municipal Solid Waste and Biomass Single Fly Ash Particles Using SR- $\mu$ XRF Spectroscopy. Analytical Chemistry, 79, 6496-6506.

CHOU, J.-D., WEY, M.-Y. \& CHANG, S.-H. (2009) Evaluation of the distribution patterns of $\mathrm{Pb}, \mathrm{Cu}$ and $\mathrm{Cd}$ from MSWI fly ash during thermal treatment by sequential extraction procedure. Journal of Hazardous Materials, 162, 1000-1006.

FARGES, F., BENZERARA, K., \& BROWN JR, G. E. (2007). Chrysocolla redefined as spertiniite. AIP Conference Proceedings 882, 223-225.

FUNATSUKI, A., TAKAOKA, M., OSHITA, K. \& TAKEDA, N. (2012) Methods of determining lead speciation in fly ash by X-ray absorption fine-structure spectroscopy and a sequential extraction procedure. Analytical Sciences, 28, 481-490.

GOH, S. W., BUCKLEY, A. N., LAMB, R. N., ROSENBERG, R. A. \& MORAN, D. (2006) The oxidation states of copper and iron in mineral sulfides, and the oxides formed on initial exposure of chalcopyrite and bornite to air. Geochimica et Cosmochimica Acta, 70, 2210-2228. 
GÓMEZ ARIZA, J. L., GIRÁLDEZ, I., SÁNCHEZ-RODAS, D. \& MORALES, E. (2000)

Selectivity assessment of a sequential extraction procedure for metal mobility characterization using model phases. Talanta, 52, 545-554.

HSIAO, M. C., WANG, H. P., CHANG, J. E. \& PENG, C. Y. (2006) Tracking of copper species in incineration fly ashes. Journal of Hazardous Materials, 138, 539-542.

HUGGINS, F. E., SHAH, N., HUFFMAN, G. P. \& ROBERTSON, J. D. (2000) XAFS spectroscopic characterization of elements in combustion ash and fine particulate matter. Fuel Processing Technology, 65-66, 203-218.

JACOB, K. T., FITZNER, K. \& ALCOCK, C. B. (1977) Activities in the spinel solid solution, phase equilibria and thermodynamic properties of ternary phases in the system $\mathrm{Cu}-\mathrm{Fe}-0$. Metallurgical Transactions B, 8, 451-460.

KARLFELDT FEDJE, K., EKBERG, C., SKARNEMARK, G., PIRES, E. \& STEENARI, B.-M. (2012) Initial studies of the recovery of $\mathrm{Cu}$ from MSWI fly ash leachates using solvent extraction. Waste Management \& Research, 30, 1072-1080.

KARLFELDT FEDJE, K., EKBERG, C., SKARNEMARK, G. \& STEENARI, B.-M. (2010) Removal of hazardous metals from MSW fly ash - An evaluation of ash leaching methods. Journal of Hazardous Materials, 173, 310-317. 
KARLFELDT, K. (2006) Characterisation and speciation of metals in ash. Thesis for the degree of Master of Science, Department of Chemical and Biological Engineering, Environmental Inorganic Chemistry, Chalmers University of Technology

KARLSSON, S., CARLSSON, P., ÅBERG, D., KARLFELDT FEDJE, K., KROOK, J. \& STEENARI, B.-M. (2010) What is required for the viability of metal recovery from municipal solid-waste incineration fly ash? - Design and assessment of a process plant for copper extraction. Proceedings of LINNAEUS ECOTECH'10 Nov 22-24, 2010, Kalmar, Sweden.

KIRBY, C. S. \& RIMSTIDT, J. D. (1993) Mineralogy and surface properties of municipal solid waste ash. Environmental Science \& Technology, 27, 652-660.

LASSESSON, H. (2013) Speciation of copper in ashes from municipal solid waste combustion. Department of Chemical and Biological Engineering, Industrial Materials Recycling. Chalmers University of Technology.

LASSESSON, H. \& STEENARI, B.-M. (2013) Speciation of Copper in Ash from a FluidizedBed Boiler Fired with Municipal Solid Waste. Energy \& Fuels, 27, 3891-3897.

MATHEWS, T., HAJRA, J. P. \& JACOB, K. T. (1993) Phase relations and thermodynamic properties of condensed phases in the system calcium-copper-oxygen. Chemistry of Materials, 5, 1669-1675. 
NEUMANN, J. P., ZHONG, T. \& CHANG, Y. A. (1984) The Cu-O (Copper-Oxygen) system. Bulletin of Alloy Phase Diagrams, 5, 136-140.

PEARCE, C. I., PATTRICK, R. A. D., VAUGHAN, D. J., HENDERSON, C. M. B. \& VAN DER LAAN, G. (2006) Copper oxidation state in chalcopyrite: Mixed Cu $d^{9}$ and $d^{10}$ characteristics. Geochimica et Cosmochimica Acta, 70, 4635-4642.

RAVEL, B. \& NEWVILLE, M. (2005) ATHENA, ARTEMIS, HEPHAESTUS: data analysis for X-ray absorption spectroscopy using IFEFFIT. Journal of Synchrotron Radiation, 12, 537-541.

SCHLUMBERGER, S. \& BÜHLER, J. (2012) Urban mining: Metal recovery from fly and filter ash in Waste to Energy plants. Ash Utilisation 2012 - Ashes in a Sustainable Society. Stockholm, Sweden, Värmeforsk (Swedish Thermal Engineering Research Institute).

SCHLUMBERGER, S., SCHUSTER, M., RINGMANN, S. \& KORALEWSKA, R. (2007) Recovery of high purity zinc from filter ash produced during the thermal treatment of waste and inerting of residual materials. Waste Management \& Research, 25, 547-555.

STROUPE, J. D. (1949) An X-Ray Diffraction Study of the Copper Chromites and of the "Copper-Chromium Oxide" Catalyst. Journal of the American Chemical Society, 71, 569-572.

SUŁOWSKA, J., WACŁAWSKA, I., SZUMERA, M. \& OLEJNICZAK, Z. (2012)

Characterization of thermally induced of crystalline phases in CuO-containing silicate-phosphate glasses. Journal of Thermal Analysis and Calorimetry, 108, 657-663. 
SUTHERLAND, R. A. \& TACK, F. M. G. (2003) Fractionation of Cu, Pb and Zn in certified reference soils SRM 2710 and SRM 2711 using the optimized BCR sequential extraction procedure. Advances in Environmental Research, 8, 37-50.

TAKAOKA, M., SHIONO, A., YAMAMOTO, T., URUGA, T., TAKEDA, N., TANAKA, T., OSHITA, K., MATSUMOTO, T. \& HARADA, H. (2008) Relationship between dynamic change of copper and dioxin generation in various fly ash. Chemosphere, 73, S78-S83.

TAKAOKA, M., YAMAMOTO, T., SHIONO, A., TAKEDA, N., OSHITA, K., MATSUMOTO, T. \& TANAKA, T. (2005) The effect of copper speciation on the formation of chlorinated aromatics on real municipal solid waste incinerator fly ash. Chemosphere, 59, 14971505.

TESSIER, A., CAMPBELL, P. G. C. \& BISSON, M. (1979) Sequential extraction procedure for the speciation of particulate trace metals. Analytical Chemistry, 51, 844-851.

TIAN, S., YU, M., WANG, W., WANG, Q. \& WU, Z. (2009) Investigating the Speciation of Copper in Secondary Fly Ash by X-ray Absorption Spectroscopy. Environmental Science \& Technology, 43, 9084-9088.

TUAN, Y. J., WANG, H. P., CHANG, J. E., CHAO, C. C. \& TSAIA, C. K. (2010) Speciation of copper in the thermally stabilized slag. Nuclear Instruments and Methods in Physics Research, Section A: Accelerators, Spectrometers, Detectors and Associated Equipment, 619, 316-318. 
USERO, J., GAMERO, M., MORILLO, J. \& GRACIA, I. (1998) Comparative study of three sequential extraction procedures for metals in marine sediments. Environment International, 24, 487-496.

VAN DER LAAN, G., PATTRICK, R. A. D., HENDERSON, C. M. B. \& VAUGHAN, D. J. (1992) Oxidation state variations in copper minerals studied with $\mathrm{Cu} 2 \mathrm{p}$ X-ray absorption spectroscopy. Journal of Physics and Chemistry of Solids, 53, 1185-1190.

YU, M., TIAN, S., CHU, W., CHEN, D., WANG, Q. \& WU, Z. (2009) Speciation of zinc in secondary fly ashes of municipal solid waste at high temperatures. Journal of Synchrotron Radiation, 16, 528-532. 